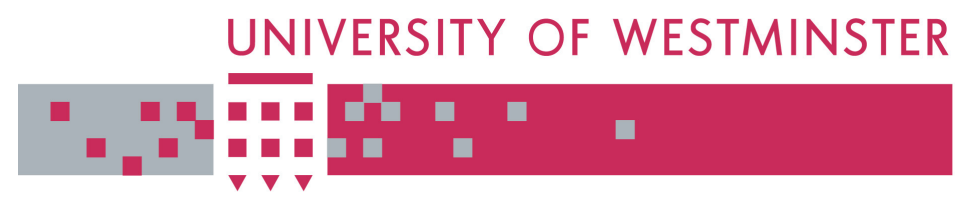

\title{
WestminsterResearch
}

http://www.wmin.ac.uk/westminsterresearch

\section{Music, radio and the record business in Zimbabwe today.}

Paddy Scannell

School of Media, Arts \& Design

This is an electronic version of an article published in Popular Music, 20 (1). pp. 13-27, April 2001. Popular Music is available online at:

http://journals.cambridge.org/action/displayJournal?jid=PMU

Copyright @ 2001 Cambridge University Press

The WestminsterResearch online digital archive at the University of Westminster aims to make the research output of the University available to a wider audience. Copyright and Moral Rights remain with the authors and/or copyright owners. Users are permitted to download and/or print one copy for non-commercial private study or research. Further distribution and any use of material from within this archive for profit-making enterprises or for commercial gain is strictly forbidden.

Whilst further distribution of specific materials from within this archive is forbidden, you may freely distribute the URL of WestminsterResearch.

(http://www.wmin.ac.uk/westminsterresearch).

In case of abuse or copyright appearing without permission e-mail wattsn@wmin.ac.uk. 


\title{
Music, radio and the record business in Zimbabwe today ${ }^{1}$
}

\author{
PADDY SCANNELL
}

\section{Introduction}

Radio and the recording business have, since the beginning of the last century, had a profound impact upon existing musical life whenever and wherever they have decisively and irreversibly established themselves. Their arrival restructures and redefines the social relations of music in many aspects of its production, performance and reception. Radio and recording technologies have had a significant impact on the livelihoods of all those who one way or another try to make a living from music (composers, performers and - in Europe - publishers, for instance). Performance itself is transformed as new norms are set in place which call for new levels of technique and interpretation. Finally the conditions of musical reception are reconfigured and new 'taste publics' emerge, potentially in conflict with each other, as musical life is totalised into a new and complex unity.

I have attempted to study these matters by examining the impact of broadcasting on British musical life (Scannell 1981; Scannell and Cardiff 1991, pp. 181-223; Scannell 1996, pp. 58-74). Here I offer a more limited study of the impact of radio and the recording business on the southern African country of Zimbabwe. There are significant points of similarity and difference between the historical study of musical life in Europe on the one hand, and a contemporary study of a recently established African country, as I will try to indicate throughout this article. At the same time I wish briefly to reflect upon what is at stake in attempts such as these to study the musical life of societies.

The phrase 'musical life' is carefully chosen. It indicates an effort to think about the meaning and significance of music in a particular way, as a matter of (everyday) human existence which encompasses both the historical life of societies and the life-as-lived of individual social members. It is based on Martin Heidegger's attempt at a fundamental ontology of everyday existence in which the key question is: 'What kind of being do we, as humans, have?' His celebrated answer is firstly that human being is being-in-the-worth (Heidegger 1962; Dreyfus 1991). This is expressly and polemically posed against the still prevalent tendency to locate human being in the head (the philosophy of consciousness; the Cartesian cogito). For Heidegger (and here) existence is taken as, in the first instance and of necessity, a practical not a theoretical matter. It is taken as given. And, secondly and crucially, this being in the world is always and unavoidably being-in-a-world-of-concern. We are the being for whom being itself is an issue. We are the being for whom things matter. We, who confront the question of existence, are unavoidably concerned with this question. We are our concerns. What kinds of concern show up in and around music is the question that shows up here. 
Every humanly made thing, every human practice and institution can be considered as embodying and expressing a particular set of concerns, a specific totality of involvements, a care structure (Heidegger 1962, pp. 225-73; Dreyfus 1991, pp. 238-45). Music is here thought of as a care structure made up of manifold, manifest practices with specific 'localised' arrangements that differentiate particular 'musics' from others. If it is meaningful to speak of music as a singular phenomenon, the word itself stands as a place-holder for the totality of involvements that are gathered in by it. What is that totality today? The term 'world music' is not more than ten years old, at least according to debates in this journal. ${ }^{2}$ What does it indicate, if not a particular take on the fact of the historically unprecedented availability of the musics of the world which interact with and upon each other to appear as all the world's music, the music of the world? Yet how the music of the world shows up cannot be globalised into a theoretical abstraction. It always, necessarily, appears in particular situations and circumstances, in particular places for particular people(s). Any phenomenology takes as its start point the situatedness of existence, its deictical components of time and place and person $(\mathrm{s}),{ }^{3}$ and tries to give an adequate account of the phenomenon in question by letting it show itself as itself, as that which it is. Factical life is what is always under investigation. So that here 'musical life' is meant and understood in its given facticity, as it appears in situ, in Zimbabwe, in the specificity of its ordinary, everyday being. ${ }^{4}$ In its own ways, music worlds and how it does so - where, when and for whom - is the preliminary 'object' of investigation. ${ }^{5}$

\section{The recording business and the professionalisation of music in Zimbabwe}

Music is always and everywhere, in the first instance, a produced and performed social and sociable practice. It is always the case that the production of an accomplished performance in public requires practice, patience, skill and talent so that the emergence of musical performance as a specialised trade or craft whereby the musician makes a living somehow or other has a history in Europe that goes back at least to the fourteenth century (Scholes 1955, pp. 837-9). So too in Africa, where kings and chiefs have for many centuries had court poets and musicians to sing their praises and cater for their musical needs. Kirby (1968, pp. 47-8) quotes a description, written by a Portuguese priest in 1586, of such musicians and their instruments at the court of an Ethiopian chieftan.

The mechanisation of music in the early twentieth century called for new forms of musical organisation as its industrialisation and commodification threatened the livelihoods of performing musicians. Questions of copyright arose in complex new ways, giving rise to the legal recognition of rights of mechanical reproduction (records) and performing rights (any public performance of a work, live or recorded). In Britain, the Musicians' Union (founded 1921) was soon locked into negotiations with the $\mathrm{BBC}$ on many aspects of the performance of live and recorded music on radio. By the end of the 1930s the BBC was paying the Performing Right Society $£ 337,000$ a year, which amounted to 54 per cent of the Society's annual income. In the words of William Boosey, one of the leading music publishers, broadcasting was 'a juggernaut' that appeared to trample over the interests of all those who one way or another tried to make a living from music.

Perhaps so, but the combined effect of the coming of radio and recording in Britain was to create new opportunities for musicians to make a living not only 
from live performance in public venues (previously their main source of income) but also from live performance on radio, record sales and performing and mechanical rights from air-plays on radio and elsewhere. The net effect of new technologies for recording and distributing music was to focus the minds of musicians both on how to avoid their own exploitation by radio and record companies while at the same time seeking to exploit both to their own financial advantage. It was this double effect that accelerated the professionalisation of music in the early decades of the century in the UK.

This process seems to be at a very similar stage in Zimbabwe today. The recording business is presently very much a cottage industry. There are a handful of recording companies in Harare, mainly of South African origin. ${ }^{6}$ They include the Zimbabwe Music Corporation (ZMC), Record and Tape Promotions (RTP), Gramma and Vibrant. The only indigenous company is High Density Records, set up in 1995 by Tendai Mupfurutsa. Mupfurutsa performs 'barbed wire' (hybrid) music as Prince Tendai with his group, Midnight Magic. ${ }^{7}$ His newly formed company not only seeks to support local and African music, its studio has professional musicians on standby to assist those musicians who do not have backing groups.

In South Africa, leading groups and singers are digitally recorded on CD and thus can sell in global markets. The Soweto String Quartet or Sibongile Khumalo, for instance, are recorded in South Africa by leading transnational companies not just for local consumption but to be marketed worldwide. There is a music industry in South Africa (Impey 1998). ${ }^{8}$ In Zimbabwe there is none. Zimbabwean performers - even the most famous - are sold on tape cassettes and the quality of the recordings is poor by contemporary international standards. Even so, tapes are expensive $(Z \$ 65)^{9}$ and beyond the pocket of most Zimbabweans. In spite of the fact that sales are pretty well exclusively local, ${ }^{10}$ the most popular artists, such as Leonard Dembo, can notch up impressive sales of up to 250,000 tapes or more. Sales of 10,000 and beyond are regarded as indicating a hit in the local market.

Musicians will not necessarily reap the economic rewards of their sales. Until a recent crackdown, the piracy of tapes was an endemic problem. Johannes Brusila (1998, pp. 53-4) offers a useful account of the nature and the extent of this problem. He suggests that, in very approximate percentages, the music market in Zimbabwe in the 1990s consists of 15 per cent vinyl records, 55 per cent legally recorded cassettes and 30 per cent illegally copied cassettes (under which category he includes home copying). Bootleg cassettes for financial gain are produced in one of two ways. There is firstly 'menu copying', a term coined by a retailer in Harare (Brusila 1998, p. 53). On the streets of the capital you can see men with a double-deck cassette player and a menu of tapes. Customers can order their own compilations from the menus on offer and collect them later in the day. This is cheap but, as Brusila notes, the quality of the recording is not very high.

The other and perhaps major source of illegal cassettes is industrial piracy, whereby high-quality copies of legally produced originals are mass produced for sale in the markets of Harare and elsewhere. Brusila describes how, in the early 1990s, the owner of the largest retain chain in Zimbabwe had a visitor from a company in the Arabian Gulf where international copyright conventions have not been ratified. The visitor offered to provide very cheap, high-quality copies of whatever the owner chose and to get them to him in Harare. Brusila notes that there is no evidence that any part of the legitimate music business in Zimbabwe is involved in the production or distribution of pirate tapes. He does not follow up his anecdote 
about the 'Dubai connection' with further evidence of where bootleg tapes are produced or how they get into the country. Nevertheless, there is a flourishing blackmarket business in the production and distribution of illegal audio and video cassettes that extends well beyond the confines of Zimbabwe itself. Early in 1996, police confiscated over 20,000 pirated CDs, video and audio cassettes belonging to a Harare-based syndicate with links in Nigeria, Zaire, Tanzania, Zambia and South Africa. High-quality pirated cassettes of leading Zimbabwean artists were selling on the streets for $Z \$ 25$ against the standard shop-price of $Z \$ 65$ for the legal originals. ${ }^{11}$

It is not only street-traders and pirates who are ripping off local musicians. Some musicians are only semi-literate. Some are taken advantage of by local recording companies who do not deliver the full royalty payments to which the musicians are entitled. It was suggested to me that Zimbabwean musicians were more likely to get a better deal from overseas recording companies (on the rare occasions that this happens) than from local businesses. ${ }^{12}$ In the face of their widespread exploitation, Zimbabwean musicians have begun to organise themselves to protect their interests, as British musicians did in the early twentieth century. In September 1995 the Music Writers Association was formed to create professional relations between the music writers, musicians, promoters and recording companies. ${ }^{13}$ Though the Zimbabwean Union of Musicians (ZUM) has been in existence for some years, it is poorly organised ${ }^{14}$ and is perceived in the country as acting only on behalf of musicians based in Harare. In Mutare (in the eastern highlands), a new Manicaland Association of Musicians (MAM) was launched in March 1996, because ZUM had failed to implement outreach programmes. The aims of the association included the creation of performing arts centres in the region and a communal approach to acquiring instruments with MAM ordering equipment on behalf of individual musicians. ${ }^{15}$

This last concern points to the great difficulties, for Zimbabwean musicians, of getting hold of modern musical instruments and equipment, ${ }^{16}$ a problem which the Manicaland Association of Musicians' proposal attempted to address. There have been suggestions that the National Arts Council of Zimbabwe might purchase and make available a common pool of equipment for Zimbabwean musicians, but the Council has very little disposable resources for such purposes. ${ }^{17}$ Beyond costs, there is the difficulty of obtaining equipment. There is only one music shop in Harare and only one company which manufactures musical instruments. The cost is prohibitive. Instruments are four times their retail price in South Africa. ${ }^{18}$ High Density Records is unique in providing not only backing but also instruments for aspiring local artists when they come to the studio.

How do Zimbabwean musicians make a living these days? Their main sources of income are from live performances (mainly in clubs and pubs), and from recording sales. There is also radio. Each year the Zimbabwean Broadcasting Corporation (ZBC) pays close to Z $\$ 1$ million to the Zimbabwe Music Rights Association (ZIMRA) for the copyright music played on their radio stations. ${ }^{19}$ At present, over 60 per cent of the income received by ZIMRA goes overseas. The rest is distributed amongst the 450 or so members of the Association, based on the number of air-plays their music has over the year (ZBC supplies the stations' daily playlists as the basis for calculating who receives what amount). At the top of the scale, Thomas Mapfumo with something like 250 plays of his music per year receives three to four thousand dollars. At the other end, Zindi, who administered ZIMRA, received Z\$80 for half a dozen plays of his music in the year! ${ }^{20}$ 


\section{Music and radio in Zimbabwe}

The Zimbabwean Broadcasting Corporation - as its very name implies - is modelled in many crucial respects on the BBC. ${ }^{21}$ Indeed the BBC was called in to redesign the radio services shortly before independence in 1980. Is it surprising that Zimbabwe's national radio services were rearranged to the very same format that the BBC had adopted ten years earlier, after one of the most bruising internal debates in its history? Broadcasting in the Seventies was the innocent-sounding title of the document which set out plans for the restructuring of national radio in the UK into four channels, Radios 1, 2, 3 and 4: three of them catered to different kinds of music taste publics, one (R4) was a 'talk' channel. ${ }^{22}$

The structure devised for ZBC national radio was essentially the same: four channels called Radios 1, 2, 3 and 4. The contents of the channels were designed to cater for the particular historical and cultural context of a newly liberated country with a remaining fractional settler population. Radio 1 (in English) was for the whites. ${ }^{23}$ Radio 2 was for the Zimbabwean population as a whole. It broadcast mainly in Shona and Ndebele with occasional programmes for the six other recognised language communities in the country. Radio 3 was a pop radio channel in English, but with black and white DJ presenters. Radio 4 was an education channel for cultural and 'development' broadcasting.

$\mathrm{ZBC}$ delivers radio and television services, but the former reach a much larger audience in all parts of the country. TV1 reaches roughly 1.2 million viewers daily (about 10 per cent of the population of 10.5 million), almost wholly based in urban areas. ${ }^{24}$ The two key radio stations (2 and 3) both reach 96 per cent of the country on VHF (R2), FM and Short Wave (R2 and R3). Radio 2 has 3.7 million listeners (2 million Shona, 1.7 million Ndebele), i.e. a third of the population, while Radio 1 reaches about 1 million listeners each day, mainly in urban areas. Both stations are partly financed by spot advertising. Advertising income from Radio 2 (the most profitable station) is used to subsidise the noncommercial educational station, Radio 4. 86 per cent of listeners to Radio 2 are in the lowest expenditure group (E), spending from nothing to $\mathrm{Z} \$ 600$ a month. 72 per cent of listeners to Radio 3 are in the highest group $(\mathrm{AB})$ with a disposable monthly income of over $\mathrm{Z} \$ 3000$. Thus, though many more people listen to Radio 2 than Radio 3, they are much, much poorer. This may explain why, as one interviewee put it to me, something of a stigma is attached to listening to Radio 2. The station was 'weird', 'not modern', 'country stuff', 'African'. I was told by a friend that some people would switch off Radio 2 before visitors or neighbours came in, so as not to be found listening to the station. Radio 3, although its audience is predominantly urban and a third the size of the audience for Radio 2, has a better signal and clearer reception throughout the country. Reception of Radio 2 is poor in Bulawayo (where the majority population is Ndebele) and outlying rural areas. Radio 3, moreover, is the only station that transmits in stereo. Poor reception, a lower quality signal and acoustics may contribute to the unsophisticated image that Radio 2 has in some (mainly urban) quarters.

Radio 2 now broadcasts only in Shona and Ndebele. ${ }^{25}$ The same news bulletins are broadcast in each language, one after the other, through the day. And the same procedure applies, in the course of the week to other programmes: a slot for women in Ndebele means there will be a similar slot on another day in Shona. A programme for children in Ndebele at 4.15 on Fridays is matched by one in Shona at 
the same time on Mondays. Although the bulk of the output on Radio 2 is music, the most popular programmes are interactive, drawing in the station's audience in various ways. The three most popular shows, according to the most recent research into radio listening preferences, ${ }^{26}$ are (in order): Kwaziso (a request programme), the clear favourite across the whole country, followed by Chakafukidza (a discussion programme that focuses on domestic and family issues) and Zviziviso (death notices). The last of the three began as a five minute information service before the midday news bulletins, but details of deaths and funeral arrangements flowed into the station at the rate of hundreds a week, so that at present there are three tenminute slots each day before the one o'clock and eight o'clock news and after the late evening news at ten o'clock. Request programmes are scheduled at peak listening hours each day, between 12 noon and 2.30 in the afternoon. ${ }^{27}$ This is the time when rural people have returned from the fields for a midday rest before returning to work for a few hours in the late afternoon. ${ }^{28}$

The music played on Radio 2 is one-third African and two-thirds local Zimbabwean. This, in effect, means music from South Africa and Zaire ${ }^{29}$ on the one hand, and Shona and Ndebele music on the other. Thomas Mapfumo and other leading Zimbabwean musicians can be heard regularly on Radio 2, while their tracks get few plays on Radio 3. Some system of proportional representation is needed to accommodate the musical preferences of the two largest communities in the country, but Ndebele music is in short supply while there is an abundance of Shona music. I was told there were maybe seventy Shona bands who recorded their work and no more than half a dozen Ndebele groups. Still, according to the head of Radio 2, this was not such a big problem. Ndebele music is similar to South African music, so that is what is played..$^{30}$ Fred Zindi, that ardent defender of local musicians, complained (when I interviewed him) of too much South African music on Radio 2 and dubbed it 'Radio South Africa'.

The most popular slot on Radio 3 is Afro-pop (33 per cent), ${ }^{31}$ which is ahead by some distance of reggae ( 22 per cent) and request programmes (16 per cent) in the survey of favourite programmes on the station, undertaken in 1994 by Research International Zimbabwe (Appendix E in Mano 1995). These are the aggregated results. When they are studied in terms of preferences in the main urban areas throughout the country (Harare, the capital city; Bulawayo, the country's second city in the west; Mutare in the east; Masvingo to the south; and Gweru/Kwekwe in the centre) compared with the rural population (as a whole), a clear difference shows up. For rural listeners, Afro-pop (37 per cent) is almost twice as popular as the second favourite, reggae (19 per cent). Afro-pop is first favourite in four of the five urban areas. It is most preferred in Harare (31 per cent) and least liked in Bulawayo, where it comes a close third (at 17 per cent) after reggae and 'Afternoon Request'. The mean average for Afro-pop in the towns is 26 per cent, more than 10 per cent less than in the country. Thus country listeners show a stronger preference for African music than town listeners though both, over all, prefer it to other forms of pop music. The clear liking for reggae is undoubtedly linked to the canonical status of Bob Marley, whose legendary performance as the main international musician invited to perform at the Independence Day celebrations, naturally drew the largest audience ever known in the country. ${ }^{32}$

\section{Zimbabwean (and South African) music}

Radio 3 has a one-in-three play policy imposed on it by ZBC. The station's DJ presenters are required to include at least one third of locally produced music in 
their play schedules. By the end of 1995 it was widely perceived that some DJs, at least, were not sticking to this, and a lively debate around the issue of 'local' music blew up in the Zimbabwean media. It began with an outspoken feature in The Sunday Mail by Fred Zindi who attacked Radio 3 as 'an enormous negative influence on today's youth in Zimbabwe'. Foreign music (rap and raga were singled out) and foreign life styles (clothes from London) were the 'in thing' and symptomatic of the continuing dominance of Western cultural values which were supposed to have been challenged with the advent of independence. The thrust of Zindi's attack, however, was not really moral decline in Zimbabwean youth, but the economic decline of Zimbabwean musicians who were not getting their dues from radio. If ZBC played more local music, the Zimbabwean Music Rights Association would have more money to distribute among local artists who, he argued, deserved to benefit from this money (Sunday Mail, 28 January 1996).

A few weeks later, Zindi was invited to take part in a live studio debate of the issue on Radio 2. It was, to judge from press accounts, an acrimonious debate in which 'self-hating Africans with pleasant, distinct Rhodesian accents and attitudes' were accused of turning Radio 3 into 'a modern day Radio Jacaranda' (the white, commercial music station in Salisbury before independence). Tendai Mapfurutsa, backing up Zindi, dubbed radio 3 'Radio Anglo-America' and claimed that 'on a good day' local musicians got only 5 per cent of air time on the station (Horizon, 26 March 1996, p. 26).

For Zindi it was a straightforward issue. Local music means music played by local musicians. Reggae or Zairean rumba is, in his view, local music so long as it is played by local artists. In South Africa, at the same time that Zindi was raising the temperature on the issue in respect of $\mathrm{ZBC}$, the $\mathrm{SABC}$ was required by the terms of the Broadcasting Act (1995), to regulate music on radio in order to protect South African music. The Act defines broadcast music as South African if it complies with at least two of the following requirements:

- the lyrics (if any) are written by a South African citizen,

- the music is written by a South African citizen,

- the music or lyrics are principally performed by musicians who are African citizens, and

- the musical work consists of a live performance which is wholly transmitted and/or recorded in the Republic of South Africa. (SABC 1995, pp. 123-4)

It is a safe generalisation that wherever quotas are imposed by broadcasters on the contents of their programme output, they do so, in the first place, in response to lobbying from local interests who seek to maximise benefits to themselves from the opportunities that broadcasting seems to promise and, at the same time, to minimise benefits to 'foreign' interests. In the case of television, the key issue always revolves around protecting a local content and a local production industry from imported North American television programmes. In the case of radio, the issue invariably revolves around music quotas to protect local musicians and the local music business.

Broadcasters rationalise their response to such pressures as acting not on behalf of those who lobby them, but in the interests of their audiences. These are generalised as members of the nation-state within which the institutions of broadcasting are situated. National broadcasters (the BBC, ZBC, SABC and others) claim to act 'in the national interest' which translates into notions of 'national culture' which they must on the one hand protect from erosion by foreign cultures, and on 
the other hand advance by active promotion in their programmes and schedules. Thus it appears quite natural for the SABC to act on behalf of South African music and for ZBC to act on behalf of Zimbabwean music.

It could be argued, however, that what is now called, unproblematically, 'South African music', did not exist before 1994. Nor did what is now called 'Zimbabwean music' exist before 1980. This does not mean, of course, that there was no indigenous music in either of these countries before these dates. It means rather that there was nothing which was formally recognised, politically, as the music of these countries before their liberation from the domination of white minorities. In the colonial/apartheid era, music was split along racial grounds. The twelvevolume Standard Encyclopaedia of Southern Africa (SESA), published in 1973, may be read as a definitive effort to define the knowable world from an Afrikaans perspective. It is instructive to see how 'music' is defined and described by an encyclopaedia whose world view is underpinned throughout by apartheid. 'Music' turns out to be, of course, the music of the whites and is traced back to the efforts of early settlers in the Cape to establish and promote a public musical life and culture for themselves. The music in question is European. There is no evidence of indigenous, white South African composers of any note, and so the entry on 'music' traces efforts to establish musical academies, concert halls and so on, on European lines, and pays considerable attention to an invented 'native' tradition of Afrikaans 'folk music'. This was the meaning of 'music' in South Africa during the apartheid era (SESA 1973, Volume 8, pp. 4-12).

To find out about the music of the black South African peoples in the encyclopaedia, it is necessary to search under the category of 'Bantu music'. Bantu is the generic term used, during the apartheid period, for the African population whose music is described in traditional terms by P.R. Kirby, author of the definitive study of 'native music' at that time (Kirby 1968). He concludes his brief entry by noting that 'the missionary influence, urban life and the ubiquitous gramophone have tended to sweep away the original music of the Bantu, which is being replaced by imitations of the idioms of Europe and America'. However, in spite of all their efforts, 'no Bantu composer of South Africa has yet succeeded in emulating completely the musical culture of Europe' (SESA 1973, Volume 2, pp. 132-4). Under the heading 'Pop Music' there are two paragraphs that note the impact on white South African youth of North American and British Pop since Elvis Presley (SESA 1973, Volume 8, p. 657).

Thus, I would argue, there is nothing before the end of the apartheid period that is (or could be) recognised as South African music. Original, indigenous music that is produced in the country itself is, overwhelmingly, created by the subject, black population. But this township music - the music of South Africa - is only, could only be, recognised and named as such when the apartheid period ended. The intense political struggle for freedom which culminated in the first democratically elected government of the 'new' South Africa in 1994 had the effect, inter alia, of liberating the music of the majority of the population. It was now set free for recognition and acceptance as 'South African music' - an acknowledged and meaningful category to be (for instance) protected and advanced as such by the reformed, post-apartheid South African Broadcasting Corporation which had hitherto operated a Radio Bantu service for black listeners to implement the state policy of apartheid. ${ }^{33}$

I have discussed, in a little detail, the emergence of something now called 
'South African music', in order to indicate what is at stake in speaking of 'Zimbabwean music' in that country today. The name itself celebrates the liberation of the vast majority from the rule of white settlers in a country whose colonial name Rhodesia - eponymously embodied British imperialism. In Rhodesia, as in the old South Africa, the original indigenous music of the country was overwhelmingly produced by the 'native' black population. It is hard to see how one could meaningfully speak of 'Rhodesian music'. The only music that the 'Rhodies' produced were the deplorable Troopiesongs for the white soldiers in their colonialist war against the black population in the 1960s and 1970s. ${ }^{34}$ Thus, the moment of independence, which gave birth to the African nation-state of Zimbabwe, freed up already-existing musical life and practices so that they achieved public recognition and legitimacy as 'Zimbabwean music'.

\section{The meaning of taste}

It is on behalf of, and in the name of, such music that local musicians begin to organise themselves, and that broadcasting imposes a one-in-three play policy. It is this music that people who now think of themselves as Zimbabweans (whereas they never, ever thought of themselves as Rhodesians) accept and recognise as their music; music that is now (and for the first time) routinely, familiarly and ordinarily available for them through radio and cassettes. Some indications of how Zimbabweans think about their music today can be gleaned from the debate about the play policy of ZBC outlined above. On the one hand, Tonderai Makinawa argues that 'local music is not a reflection of Zimbabwean culture':

There are a number of artists who imitate foreign sounds. By becoming followers of Western vibes, these artistes place themselves in the same boat at the Western musicians. Listeners will then have no choice but to compare the imitating local artiste to the Western idol. Usually the copycat loses. Can radio stations then be blamed for such a failure? Can it be said that we are promoting African values when we promote artistes who are Zimbabweans by birth, but express themselves in Western style? Very few artistes in Zimbabwe promote African music. Musicians such as Thomas Mapfumo, Stella Chiweshe and Sekuru Gora are genuine local artistes. (The Manica Post, 23 February 1996)

By contrast a respondent to the critics of Radio 3 had stoutly declared, a few weeks earlier in the same newspaper, that he could not, in truth, do without 'country, rock and roll, soul, reggae, raga, rumba etc.':

I am not discarding our local music, but we cannot do without foreign music. Too much of local music will become monotonous. So Mr Mutasa, tune in to our favourite station. Radio 3 is our window to the world at large. So to all of you Radio 3 DJs I say keep up the good work. Local musicians, I also urge you to keep on with the good work because we Zimbabweans and the world at large need your music. (S.M.: Mutare, Manica Post, 2 February 1996).

In taken-for-granted ways, both writers, in spite of their different perspectives, think of themselves quite naturally as Zimbabweans, and assume that there are such things to be spoken of as Zimbabwean culture, Zimbabwean musicians and a local, Zimbabwean music. This music, whatever it is, is thought of as a phenomenon in its own right which stands in a complex relationship with, on the one hand African music and, on the other, foreign, Western music. While much could be said about the implications of the particular tastes that are expressed here, I would like to reflect on what it means to have such tastes, for I take it that a taste for (or 
against) local music did not exist before independence. This, again, is not to suggest that local music did not exist before independence, but rather that after independence it becomes available in quite new ways that allowed the formation of new kinds of taste publics.

The term 'taste publics' was coined by William Weber to describe the audiences who attended new kinds of musical concerts in early nineteenth century Europe (Weber 1975, p. 10). These concerts extended and widened a process begun by the development of opera in the late seventeenth century, namely the detachment of music from the traditional rituals and ceremonies (civil and sacred) in which it was embedded and of which it was an integral part. As music was freed from the domain of tradition it began to emerge for the first time as music (music in itself), and as a matter of taste. As music entered into new forms of publicness in which it stood alone as a cultural form in itself - uncoupled from religious, political and social life - it became a matter of choice, a life-style option for new, paying elites, of whom the concert-going publics in Vienna, Paris and London, described by Weber, were among the first. Taste is thus a distinctively modern thing. A taste for music always presupposes that music has already become a matter of choice, a preference, which defines itself as a liking for certain kinds of music and a dislike of others. In the context of tradition, the very idea of music as a matter of taste is an anachronism, for it is not an option but rather a taken-for-granted, integral component of the tradition itself as expressed in ritual, ceremonial and social practices.

Thus to have a taste for music - for local music - in Zimbabwe is indicative that this music has been freed from tradition. It is available in new ways, for new kinds of public as a matter of taste. Traditional music has not entirely vanished. It is still played on traditional instruments, ${ }^{36}$ with drums for rhythm and hosho for beat, but is identified by the instrument that provides the melodic line as mbira music. It is seldom, if ever, recorded, for there is no commercial gain to be made from traditional music (Brusila 1998, p. 52). It is needed, I was told, for ritual and ceremonies. ${ }^{37}$ It now begins to appear, abstracted from its everyday contexts, as something like 'folk music', where there is an effort at authenticity: authentic performance, in authentic style on authentic instruments. ${ }^{38}$ The aim is to preserve in its purity what was once the everyday music of people but which has now been displaced by the kind of music heard on Radio 2 and, less frequently, on Radio $3 .^{39}$

The 'forcing moment' of the new music that is the music of today's Zimbabwe was the war of liberation and the music of that struggle. The songs of the liberation struggle have been studied in a pioneering work by Alec J.C. Pongweni (1982) who analysed their content in various ways to show how the lyrics expressed the resolution of the guerrillas; their will to freedom; their understanding of the nature and causes of the war; their sense of its connectedness to the past and to past struggles (particularly the first Chimurenga against the settlers at the end of the last century). ${ }^{40}$ A fuller historical study of the historic, political and cultural significance of the lyrics of chimurenga music, such as Kimani Gecau $(1995,1997)$ has made of Kenyan songs, has yet to be published. The work in progress of Rino Zhuwarara deals, inter alia, with the strategic importance of the guerrilla radio stations in Mozambique, Zambia and Tanzania for the liberation struggle. While they had an obvious propaganda role to play, no less importantly they contributed to the morale both of the fighters and the communities that supported them by making field recordings in the bush of their chimurenga songs and broadcasting them back into 
Rhodesia. The songs were, in the words of one of the broadcasters at that time, 'the heartbeat of the revolution'. ${ }^{41}$

The best known exponent of chimurenga music is Thomas Mapfumo, Zimbabwe's most famous - most revered - musician today, whose musical development has been traced in a fascinating historical and linguistic study by Alice Kwaramba (1997). What shows up, in this account, is the complex formation of a distinctive musical style and performative idiom, a process which embodies and expresses the historic emergence of what is now recognised as Zimbabwean music. This does not mean that Mapfumo, all by himself, forged the music of a postcolonial African country. It means, rather, that Mapfumo's own personal struggle to find a new idiom that expressively embodied in words and music in performance the wider struggle - its meaning and aspirations - can be taken as exemplifying the discovery and creation of a music that is intensely, locally specific and which yet draws on and appropriates for its own concerns, contemporary popular music from elsewhere in the world; from Europe, America and the Caribbean. It is one of the virtues of Alice Kwaramba's study that it reveals these tensions with exemplary clarity as it traces the transitions in Mapfumo's music in relation to the history and politics of Zimbabwe from the 1960s to the 1990s.

It would be a mistake to think of Zimbabwean music as nationalist, though it is the expression of the emergence and continuity of an African nation. It is rather that, as part of the process of liberation, something was freed up in respect of the music. To say that it became a matter of taste is not in any way to belittle it. Taste is a complex, modern phenomenon that can be understood in a number of ways. As a matter of pure taste, music is thought of in aesthetic terms, unsullied by gross material considerations. As a matter of consumption, taste is linked to commodification and the market. As a matter of style and preference, it is linked to class and other socio-cultural indicators. But taste can also be thought of as linked to empowerment and freedom. It is as much a politically sanctioned, public matter as a matter of subjective (personal) opinion. It is an entitlement that goes with the attributes of being a person. Before independence the majority of Zimbabweans, like the great bulk of the population of South Africa under apartheid, were simply not entitled to their opinions, attitudes and tastes for they were not recognised as persons in their own right. Tastes, like opinions, are politically sanctioned attributes of modern individuals in democratic societies. The new taste publics in Zimbabwe, with their preferences for and against locally produced music, embody and express new entitlements and freedoms both in respect of music and much wider issues. They are created not by the technologies themselves but by the ways in which they are put to use in changed political, social and cultural circumstances.

Music is an essentially worldly thing, a matter of everyday matter-of-fact concern. It shows up as such in the totality of involvement sketched above: the concerns of musicians, the scheduling and programme policies of broadcasting institutions, the responses and attitudes of audience members. The music in question is now recognised in different ways by all parties as their music, Zimbabwean music, the music of Zimbabwe. Its appearance as such is the mark of its having been freed into existence as an aspect both of a new historical and political formation - the African country of Zimbabwe freed from the domination of the white minority and of the everyday lives of its members, the people of Zimbabwe. Thus what worlds in the music of Zimbabwe today is both the historical struggle that has brought it into existence and the new freedoms that come with it. 


\section{Endnotes}

1. An earlier version of this article was presented as a paper at the conference on Identities, Democracy, Culture and Communication in Southern Africa, held at the University of Natal, Durban, in January 1997.

2. The pioneering issue of Popular Music on African Music (1989, Volume 8/3) acknowledges its "'discovery" of the existence of a whole continent full of popular music' and links this to the recent 'world' music campaigns in the UK (Stan Rijven, Introduction, pp. 215-6). For recent discussions of the meaning of 'world music', see Guilbault (1997) and Van der Lee (1998).

3. The study of deixis (from Greek, 'to indicate') is a core concern of linguistic pragmatics (Levinson 1983, pp. 54-96), which takes as its object of study language as utterance, language in use. As such it is concerned with the contexts of utterances as relevant resources for the design of utterances themselves. This shows most clearly in the use of deictical expressions of time (now/then), place (here/ there) and person (me/you/they). More generally, time, place and person are the fundamental components of any worldly situation whatever, and a core concern of phenomenological enquiry. They are unobtrusively thus thematised in the following accounts and discussion.

4. The accounts that follow are based on research undertaken while I was a guest of the University of Zimbabwe from January to April 1996. I am indebted to a number of people for information on the current state of music in Zimbabwe, especially Kimani Gecau, Musa Zimunya, Fred Zindi, Professor Solomon Mutswairo, Dumisani Maraire, Richard Muzira and the Head of Radio 2, ZBC. I learned a very great deal from all of them. I am particularly grateful to Rino Zhuwarara, Chair of the English Department in the University of Zimbabwe, for his help, advice and guidance on every aspect of this study. I would like to thank Rino and his colleagues for their unfailing kindness, courtesy and friendship during my time with them.

5. Perhaps the most fundamental thing in Heidegger's radical phenomenology was the rediscovery of world; the world in which each one of us has our being; the world in all its fullness and immediacy; the world in which I am and have to be. 'It worlds. It is worlding', Heidegger was saying in his lectures in the early 1920s. See Kisiel (1995, p. 329) and cf. Scannell (1996, p. 161) on the ways in which radio worlds.

6. The Johannesburg-based company, Gallo, has had offices in Bulawayo since the 1950s and
Teal (which became Gramma in the 1970s) began operating in Salisbury in the 1960s.

7. 'Music '95: an eventful year', Major Ray. The Worker, December 1995 - January 1996. In March 1996, High Density signed a one-album contract with the Zairean rumba star, Kanda Bongo Man - the first signing of an international artist by a Zimbabwean studio (Sunday Mail, 3 March 1996).

8. The Association of the South African Music Industry (ASAMI), which represents most of the recording companies in the Republic, had (in 1995) a membership of seven major multinational recording companies, four large independent South African companies and fifty-six smaller indigenous recording companies (SABC Report 1995, p. 144).

9. At the time of my stay, in early 1996, the exchange rate was around $\mathrm{Z} \$ 15$ to the pound. At the time of writing (March 1999) it has collapsed to $\mathrm{Z} \$ 60$ to the pound.

10. Though South African music is liked and sells in Zimbabwe, the reverse is not the case. Zimbabwean musicians seldom perform in South Africa.

11. 'Weak piracy laws hamper police tape crackdown', Japhet Ncube, Horizon, February 1996, p. 24.

12. It is certainly the case, as Dave Laing has pointed out to me, that leading performers derive a significant supplementary income from overseas sales of their music as 'world music' on CD.

13. Major Ray. The Worker, December 1995 - January 1996, p. 11.

14. 'Local musicians are not united. The Zimbabwe Union of Musicians (ZUM) is toothless and has failed to address the musicians' problems. The association is dogged by power wrangles, inefficiency and petty squabbles.' Godfrey Nhari, The People, December 1995, p. 19.

15. 'Local musicians to launch association', Gilbert Chiromba, The Manica Post, 1 March 1996, p. 11. The Zimbabwe College of Music runs workshops on pop music production with equipment supplied by a donor. Students are encouraged to experiment in combining traditional instruments with modern ones like electric guitars, electronic keyboards, synthesizers, drum machines, etc. (information supplies by Richard Muzira).

16. As distinct from locally made traditional instruments: the marimba (xylophone), mbira (thumb piano), drums and hosho (gourd or rattle).

17. The NACZ has a current annual disposable budget of $\mathrm{Z} \$ 2.25$ million. It is a legacy of the 
colonial era (established in 1971) and was given its present title in 1985. It is a para-statal organisation (an arm of the Ministry of Sport, Recreation and Culture), with a mandate to encourage performing artists in music, dance, sculpture and literature. It provides some support for music associations (such as the Full Moon Group) who organise annual festivals of traditional music. It makes a small grant to the Zimbabwe College of Music, founded in the colonial era for training in classical music (but see note 13 above). It thus appears to support (however minimally) traditional African music and Western classical music, but not local commercial music. The Chairman of NACZ, at the time of my visit, was Professor Solomon Mutswairo of the Dept of African Languages and Literature in the University of Zimbabwe, who supplied me with details of the Arts Council in an interview.

18. 'Local music needs support', Godfrey Nhari, The People, December 1995, p. 19.

19. ZIMRA was founded in 1980 by the British Performing Right Society. For a number of years it was in dispute with ZBC which was unwilling to pay for the use of copyright music on air. It was not until 1989 that regular annual payments have been made to ZIMRA by ZBC.

20. Interview with Fred Zindi, March 1996.

21. For a useful discussion of ZBC's formation and its public service character, see Mano (1995) (see also R $\phi$ nning 1989). Information about broadcasting in Rhodesia/Zimbabwe remains very patchy.

22. For a detailed account of the controversy surrounding Broadcasting in the Seventies, see Briggs (1995, pp. 721-810).

23. Described to me, by one interviewee, as 'a sacred cow', a refuge for those 'with one foot in Zimbabwe and the other in Britain'. It plays a considerable amount of BBC material, mainly from Radio 4.

24. There is a second television channel (TV2), with an educational/cultural remit. Nearly all the material transmitted is either North American or British. It is only available in Harare and has an audience of 100,000. Most of the information in this section is taken from Mano (1995), the most up-to-date account of broadcasting in Zimbabwe.

25. The other 'minority' languages (as the Head of Radio 2 called them, when I interviewed him) - Kalanga, Venda, Tonga, Nambya, Chewa and Shangani - which in the past had occasional air time on Radio 2, have now been moved to Radio 4, with a tiny daily audience of 48,000 (1 per cent of the total radio audience). But even on Radio 4 the dominant languages are Shona, Ndebele and English, leaving other language speakers with a very small dole of programmes in their own mother tongue. A Tonga speaker from Kariba (in the Zambezi valley where the Tongan population lives) complains of the neglect of his people: 'Shona and Ndebeles are given enough time to express their views as much as they can.... When Radio 4 came into being, I thought that maybe they were going to give other tribes enough time on air. Time is being wasted on the radio presenting useless programmes such as Reggae and Western music.' (Elias Mazambuko, Parade, April 1996, p. 4) The Head of Radio 2 saw no problems in discontinuing programmes in the minority languages. All Zimbabweans can understand either Shona or Ndebele, he told me.

26. Summary Report on the Zimbabwe Nationwide Electronic Media Survey, Research International (Zimbabwe), July 1994 (See Mano 1995, Appendix C).

27. Radio 2 receives about three and a half thousand letters a week, sent mainly to the request programmes and Zviziviso.

28. Peak listening times in the towns are 6 am -8 am and $4.30 \mathrm{pm}-9.00 \mathrm{pm}$; in the country, $11.30 \mathrm{am}-2.30 \mathrm{pm}$ and $5 \mathrm{pm}-9 \mathrm{pm}$, with some seasonal variation. I was fascinated to learn from the Head of Radio 2 how the schedules are unobtrusively attuned to the rhythms of country life as much as town life. For instance, the weekly thirty-minute programme for women goes out at 2.30 in the afternoon, at which time the men are returning to the fields while the women remain behind. Farming programmes go out between 7 and 8 in the evening, the hour before dinner when the men are relaxing and the women are preparing the meal.

29. Zairean rumba is popular in many African countries. For a useful history, see Ewens (1991, pp. 126-57). Cf. Gecau (1995, pp. 563-7) for its impact on Kenyan music from the 1950s.

30. The Ndebele were originally a Zulu clan who fled from what is now KwaZulu-Natal in order to avoid paying tribute to the great Zulu warrior chief, Shaka. They settled in the south west of Zimbabwe, around Bulawayo.

31. A letter-writer to The Manica Post (2 February 1996) explains: 'To "Worried Afro-Pop Fanatic", doesn't he know what Afro-Pop means? I thought the word was self explanatory. It doesn't mean rumba from Zimbabwe but music from all over Africa, hence the DJ plays music from Zaire, Zimbabwe and all over.' See Chikuhwa (1998, pp. 344-53) for a useful, brief history of contemporary popular music in Zimbabwe, also Zindi (1985) and Impey (1998, pp. 432-5). On Afro-Pop more generally, see Barlow and Banning (1995). For an excellent survey of contemporary music 
in Africa and its historic roots, see Ewens (1991).

32. In 1979, Marley released a song called Zimbabwe at a crucial moment in the liberation struggle. This - Marley's most important political song, in the view of Robin Denselow may not, as he notes, have changed the course of the struggle, but it was an enormous boost for the Patriotic Front (the combined forces of Robert Mugabe and Joshua Nkomo) to hear it blasting out across the airwaves of Southern Africa (Denselow 1989, pp. 133-4). It was this that made Marley the obvious choice to lead the celebrations on Independence Day. For a vivid account of the impact in Zimbabwe of Marley's music and Rastafarianism, see Zindi (1985, pp. 19-22).

33. Fred Zindi heads the Department of Educational Foundation at the University of Zimbabwe. A musicians himself who used to perform on the college circuit while a student in England, he promoted a Harare group that toured England in the late 1980s. He administers the Zimbabwean Music Rights Association (ZIMRA) which collects and distributes income from performing rights royalties in Zimbabwe.

33. For an account of Radio Bantu and, in particular, its changing music policies in the apartheid era, see Hamm (1991).

34. During the war, the record shops in Salisbury sold LPs such as Troopiesongs whose cover showed grinning white soldiers in the bush holding guitars and cans of beer, and which included such numbers as 'The Gunship Calypso' and 'We Stand Alone'. Eddie Calvert, who had achieved fame in Britain with his 'singing trumpet' in the 1950s (O Mein Papa and Zambesi), and now lived in Rhodesia, turned out to perform for the Smith regime. His act, Robin Denselow notes 'included a horrendous version of "Amazing Grace" now titled "Amazing Race" (Denselow 1989, p. 135).

35. During the liberation struggle, the name Zimbabwe was illegal: mentioning it was a subversive act and a criminal offence. Alice Kwaramba, in her study of Thomas Mapfumo, notes that in his pre-Independence songs, the country is never named but simply referred to as muno (here). At Inde- pendence almost all the songs name Zimbabwe in celebration of the country's newly won freedom: 'ZimbabweYevatema' (Zimbabwe for the Blacks) 1980; 'Fairirai Zimbabwe' (Rejoice for Zimbabwe) 1980; 'Kwayedza MuZimbabwe' (It's Dawn in Zimbabwe) 1980; 'Tirikupemberera Zimbabwe' (We Are Celebrating the Birth of Zimbabwe) 1980. For further discussion of these songs, see Kwaramba (1997, pp. 83-6).

36. On 'traditional music' in Zimbabwe, see Chikuhwa (1998, pp. 331-44), Berliner (1978) and Kaemmer (1998, pp. 744-58). All define it in terms of mbira music, the music of the thumb piano', described by Stella Chiweshe ('the Queen of Mbira') as sounding like 'tuned raindrops' - a beautiful and exact description.

37. Descriptions of ritual and ceremonial performances (trance drumming and dancing which produces possession by the spirits) can be found in Mungoshi (1981, pp. 127-31) and in Godwin (1996, pp. 29-31).

38. Such, it seems to me, is the music of Dumisani Maraire (recently deceased), an ethnomusicologist at the University of Zimbabwe and one of the country's leading performers of traditional music on both marimba and (his favourite) mbira. I am grateful to him for the patient explanation he gave me of the instruments and structures of traditional African music.

39. 'Many of the traditional instruments are no longer played or used, just as many of the occasions at which they were played are no longer a significant part of the lives of many Zimbabweans.' (Chikuhwa 1998, p. 331) Traditional music on traditional instruments is now performed by Zimbabwean musicians dressed up in 'native' costumes in some of the restaurants in Harare that cater for the tourist trade.

40. According to oral tradition, the term Chimurenga was coined from the name of the great Shona warrior and legendary hero, Sorenzorou Murenga, and translates roughly as 'fighting in the Murenga style'. The liberation struggle of the 1960s was called the 2nd Chimurenga and the music of the struggle was, naturally, chimurenga music (Kwaramba 1997, pp. 4-5).

41. Details from Rino Zhuwarara, seminar paper (unpublished), University of Oslo, 26 May 1999.

\section{References}

Barlow, S., and Banning, E. 1995. Afropop! An Illustrated Guide to Contemporary African Music (Edison, NJ) Berliner, P. 1978. The Soul of Mbira: Music and Traditions of the Shona People of Zimbabwe (Berkeley, CA) Briggs, A. 1995. The History of Broadcasting in the United Kingdom, Volume V: 'Competition, 1955-1974' (Oxford) 
Brusila, J. 1998. 'The music industry of Zimbabwe: from vinyl to piracy?', in Music on Show. Issues of Performance, ed. T. Hautamäki and H. Järviluoma, Dept. of Folk Tradition, No. 25 (Tampere)

Chikuhwa, J.W. 1998. Zimbabwe: the Rise to Nationhood (London)

Denselow, R. 1989. When the Music's Over. The Story of Political Pop (London)

Dreyfus, H. 1991. Being-in-the-World (Cambridge, MA)

Ewens, G. 1991. Africa O-Ye! (Enfield)

Gecau, K. 1995. 'Popular song and social change in Kenya', Media Culture E Society, 17/4, pp. 557-75 1997. 'The 1980s background to the popular political songs of the early 1990s in Kenya', in Media, Democracy and Identity, ed. R. Zhuwarara, K. Gecau and M. Drag (Harare)

Godwin, P. 1996. Mukiwa [White Boy] (London)

Guilbault, J. 1997. 'Interpreting world music: a challenge in theory and practice', Popular Music, 16/1, pp. 31-44.

Hamm, C. 1991. “The constant companion of man”: Separate Development, Radio Bantu and music', Popular Music, 10/2, pp. 147-73

Heidegger, M. 1962. Being and Time (Oxford)

Impey, A. 1998. 'Popular music in Africa', in Africa: The Garland Encyclopaedia of World Music, Volume 1 (New York and London)

Kaemmer, J.E. 1998. 'Music of the Shona of Zimbabwe', in Africa: The Garland Encyclopaedia of World Music, Volume 1 (London and New York)

Kirby, P.R. 1968. The Musical Instruments of the Native Races of South Africa (Johannesburg)

Kisiel, T. 1995. The Genesis of Heidegger's 'Being and Time' (Berkeley and Los Angeles)

Kwaramba, A.D. 1997. Popular Music and Society. The Language of Protest in Chimurenga Music: the Case of Thomas Mapfumo, Report No. 24, Department of Media and Communication, University of Oslo (for further details contact: info@media.uio.no)

Levinson, S. 1983. Pragmatics (Cambridge)

Mano, W. 1995. Public Service Broadcasting in Zimbabwe, International Summer School Paper (University of Oslo)

Mungoshi, C. 1981. Waiting for the Rain (Harare)

Pongweni, A.J.C. 1982. Songs that Won the Liberation War (Harare)

Rønning, H. 1989. The Structure of the Media in Zimbabwe (University of Oslo)

Scannell, P. 1981. 'Music for the multitude? The dilemmas of BBC music policy, 1923-1946', Media Culture $\mathcal{E}$ Society, 3/3, pp. 243-60

1996. Radio, Television and Modern Life (Oxford)

Scannell, P., and Cardiff, D. 1991. A Social History of British Broadcasting, 1923-1939 (Oxford)

Scholes, P. 1955. The Oxford Companion to Music, 9th Edn (Oxford)

SABC. 1995. Report of the South African Broadcasting Corporation (Johannesberg)

SESA. 1973. Standard Encyclopaedia of Southern Africa, 12 volumes (Elsies River, Cape)

Van der Lee, P. 1998. 'Sitars and bossas: world music influences', Popular Music, 17/1, pp. 45-69

Weber, W. 1975. Music and the Middle Class (London)

Zindi, F. 1985. Roots Rocking in Zimbabwe (Gweru) 
